\author{
Jacek STROJNY ${ }^{1}$ \\ Małgorzata BARAN ${ }^{2}$
}

\title{
ANALYZING THE TASK-MATURITY LEVEL. THE EXAMPLE OF A POLISH PRIVATE UNIVERSITY
}

\begin{abstract}
The issue of management efficiency is an extremely important subject of theoretical considerations and a significant practical problem as well. It applies to enterprises, public institutions and non-governmental organizations. It is impossible to omit it in the context of the functioning of modern universities. There are a number of system solutions in the literature that are aimed at ensuring high efficiency. A number of process management concepts can be indicated, as well as project management methodologies. In fact, for many contemporary organizations both types of activity (project and process) are extremely important. This justifies the search for concepts combining both approaches.

The aim of the paper is to present a pilot study of the level of a task-oriented organization in one of the Polish private universities. It was assumed that the adoption of the presented approach serves to ensure high operational and strategic efficiency. To analyze the situation, the method of AHP (Analytic Hierarchy Process) was used. The task-orientated model, proposed by J. Strojny, was assessed by a group of internal experts. An assessment was made in two dimensions: the significance of the model elements and the level of maturity of the organization under study. Expert marks were agreed upon within a Focus Group Interview. Marks for criteria and a general mark on the level of maturity were aggregated using a weighted average. The results were analyzed in terms of cognitive, methodological and utilitarian aspects.
\end{abstract}

Keywords: project management, process management, systemic management, university, AHP.

\section{INTRODUCTION}

The aim of this article is to present research on the level of task-oriented organization in one of the Polish universities. It fits in with a contemporary research based on the systems approach. This approach to the organization is strongly prevalent in both, the theory and practice of management. As the subject of the study, one of the Polish universities was selected. Accordingly, the study is therefore also a comment on the discussion on the functioning of such institutions.

The systems approach to management has its roots in cybernetics ${ }^{3}$. It regards organizations as complex systems consisting of numerous elements all remaining in relationships

\footnotetext{
${ }^{1}$ Dr Jacek Strojny, Rzeszow University of Technology, Rzeszow, Poland; e-mail: jstrojny@prz. edu.pl

2 Dr Małgorzata Baran, Collegium Civitas, Warsaw, Poland; e-mail: malgorzata.baran@ civitas.edu.pl

3 more: F.E. Kast, J.E. Rosenzweig, General systems theory: Applications for organization and management, "Academy of Management Journal", 15(4), 1972, p. 447-465, M. Jackson, Systems approaches to management, Springer Science \& Business Media, New York 2007.
} 
with each other ${ }^{4}$. Organizations are open systems and they interact with their environment to obtain the resources necessary for maintaining their operations. They also transfer the results of their activity back into the environment. The process of transformating inputs into outputs should be effective and efficient. This assumption is the fundamental for economics and management sciences. In the wider context, the problem of efficiency and effectiveness of the activity is analysed by praxeology ${ }^{5}$. A system is effective and efficient only if it is able to achieve its goals and yield returns that outweigh the costs. To achieve it, an organization must be managed in an appropriate way. Approaches in management sciences, nowadays, must take into consideration many external and internal factors influencing the organization.

This paper focuses on the internal aspects of organization. The dedicated model of taskoriented organization based on systems approach was used. It takes into consideration attributes of the organization that are important from the point of view of efficiency and effectiveness. When devising the principles of the proposed investigation, the following research question was posed: What is the level of maturity of the task-oriented organization? To answer this question, the test version of the Task-Oriented Organization Model ${ }^{6}$ was used. The presented model covers three basic dimensions: strategic, operational and socio-organizational. These main criteria were-particularized into sub-criteria and, subsequently, parameters. Thus, a three-level hierarchical model was created. The condition of the company is assessed by examining the parameters. Their evaluation is carried out with the aid of a diagnostic 5-point scale of maturity, proposed by J. Strojny. The grades are then aggregated using weighted means. The weights of individual elements of the model were calculated on the basis of experts' judgements. They were obtained on the basis of pairwise comparisons using the Saaty scale ${ }^{7}$.

The aforementioned theoretical model was verified through assessment of the one of the Polish private universities. This organization was selected on the basis of three criteria: accessibility, compatibility and usability. The results obtained were analysed from a cognitive, utilitarian and methodological standpoint. The quality of the information obtained on the condition of the company was scrutinized, and the entirenness of the model and the research procedure were assessed. Their practical potential was also verified by presenting recommendations based on the analysis to the management of the organization.

\section{SYSTEMS APPROACH TO TASK-ORIENTED ORGANIZATION - A SHORT LITERATURE REVIEW}

The approach presented in this article is based on the Task-Oriented Organization Model. It rests on combining the process and project-oriented approaches into a single coherent concept of organization. Holistic concepts such as this one are typical for systems approaches. Its beginnings are rooted in the development of cybernetics ${ }^{8}$. It provides a compre-

4 more: S. Mynarski, Elementy teorii systemów i cybernetyki, Warszawa 1981.

5 more: T. Kotarbiński, Traktat o dobrej robocie, Wrocław-Warszawa-Kraków-Gdańsk 1973, T. Pszczołowski, Zasady sprawnego działania. Wstęp do prakseologii, Warszawa 1982.

6 J. Strojny, Task-Oriented Organization Model - documentation, unpublished materials, Rzeszów 2015.

7 A. Prusak, P. Stefanów, AHP - analityczny proces hierarchiczny, Warszawa 2014, p. 253-255.

8 more: A.J. Quin, Cybernetics in management, "Systems Science", Springer US, 1993, p. 199-204, Midgley, G. (Ed.)., Systems thinking, Sage, London 2003. 
hensive perspective on organizations, taking into consideration their diverse elements and the associations between them ${ }^{9}$. This allows for identifying the attributes that determine the organization's efficiency and effectiveness.

Both theoretical musings and empirical studies in the field of management seek to find the answer to the question on how to achieve high efficiency and effectiveness within organizations. Praxeology has also greatly contributed to the understanding of this topic. It was created by V. Espinas and L. von Mises and Polish academics such as T. Kotarbiński and J. Zieleniewski ${ }^{10}$. Praxeology analyses many parameters of activity, including: efficiency, effectiveness, usability, productivity, dexterity etc. ${ }^{11}$. Two of them, namely efficiency and effectiveness, are featured in this article ${ }^{12}$. The former is the basic condition of the survival of an organization, whereas efficiency should be understood as the ability to produce outcomes that outweigh expenditures. The above goal is obvious in the case of companies which are profit-oriented organizations. However, other kinds of organizations must also meet such goals in order to justify their existence in the long term. Organizations should, therefore, create added value. The second important criterion of assessing operations is the ability to achieve goals, i.e. effectiveness. In this article it was assumed that adopting a task-oriented philosophy assists in achieving high efficiency and effectiveness. The model used in our research combines the process and project approaches to create a coherent concept of organization.

Currently, process-oriented management is a widely adopted approach, both in theory and practice. The roots of process management may be traced back to the concept of BPR - Business Process Reengineering ${ }^{13}$. This approach was devised in response to the decline of the traditional concepts of management, based on planning and hierarchical organizational structures. BPR defines processes as activities that transform resources into products or services that meet the needs of customers ${ }^{14}$. However, the current definition of process-oriented management is much broader. It is tied mainly to the philosophy of ongoing development embodied by the Kaizen concept ${ }^{15}$ or methods such as TQM ${ }^{16}$ and lean management ${ }^{17}$. Customer satisfaction is, in a sense, an indicator of the quality of a process, which is also the measure of the effectiveness of undertaken activities. Effectiveness, on the other hand, is determined by the ability to focus on activities that are indispensable for creating value for customers and the skill of eliminating waste.

\footnotetext{
9 M. Mazur, Pojęcie systemu i rygory jego stosowania, „Postępy Cybernetyki” 10(2), 1987, p. 25-33.

10 W. Gasparski, Prakseologia-wariacje na temat..., „Prakseologia” 150, 2010, p. 25-34.

11 A. Mazurkiewicz, Sprawność dziatania - interpretacja teoretyczna pojęcia, „Nierówności Społeczne a Wzrost Gospodarczy", (20), 2011, p. 47-57.

12 W. Kowal, Skuteczność i efektywność - zróżnicowane aspekty interpretacji, „Organizacja i Kierowanie", 157(4), 2013, p. 11-22.

13 more: M. Hammer, J. Champy, Reengineering w przedsiębiorstwie, Warszawa 1996.

${ }^{14}$ Ibidem.

15 more: J. Singh, H. Singh, Kaizen philosophy: a review of literature, "IUP Journal of Operations Management", 8(2), 2009, p. 51-72

16 more: G.K. Kanji, Total quality management: the second industrial revolution, "Total Quality Management", 1(1), 1990, p. 3-12, T.C. Powell, Total quality management as competitive advantage: a review and empirical study, "Strategic Management Journal", 16(1), 1995, p. 15-37.

17 more: Jackson T.L. Implementing a lean management system, CRC Press, Portland 1996.
} 
Contemporary project-oriented management is an integral part of many approaches in management, marketing and logistics. This article emphasizes the role of integrating the process and project-oriented approaches. Project management can be understood as a process of "planning, delegating, monitoring and control of all aspects of the project and the motivation of those involved, to achieve the project objectives within the expected performance targets for time, cost, quality, scope, benefits and risk" ${ }^{18}$. It could be, therefore, assumed that managing projects involves applying methods, techniques, knowledge, skills, tools to project activities to meet project goals ${ }^{19}$. Implementing a project-based approach and integrating it with the process approach are a necessity for many contemporary organizations. Increasingly, more activities require the use of project management methods due to their rising complexity, time constraints and costs. This change is evident across many organizations that have, thus far, used the process approach, i.e. manufacturing companies, public institutions and universities ${ }^{20}$.

Using the project approach makes it possible to attain high effectiveness and ensure successful operations of such organizations ${ }^{21}$. This, in turn, has a positive effect on their competitive position. Using the project-oriented approach has an influence on the organizational culture and structure, principles of operation and management methods of the organization $^{22}$. The growing popularity of the project-oriented approach requires seeking new ways of optimizing organizational solutions associated with its implementation. Diverse definitions of organizations employing the project-oriented approach are being devised both, as part of international standards (PMI, IPMA, PRINCE2) and independently ${ }^{23}$. Some

${ }^{18}$ OGC - Office of Government Commerce, Managing Successful Projects with PRINCE2 ${ }^{\mathrm{TM}}$, TSO, London 2009, p. 5.

${ }^{19}$ more: PMI - Project Management Institute, Organizational Project Management Maturity Model (OPM3®) - Third Edition, PMI, Pennsylvania 2013, IPMA - International Project Management Association, IPMA Organizational Competence Baseline - The standard for moving organizations forward, Zurich 2013.

${ }^{20}$ more: M. Baran, J. Strojny, Kompleksowe podejście do zarzadzania projektami na przykładzie uczelni wyższej, „Przedsiębiorczość i Zarządzanie”, XIV.12.I, 2013, p. 247-262.

21 This issue was discussed among others in: J. Strojny, Organizacyjne i proceduralne uwarunkowania zarzadzania projektami $w$ jednostce samorzadu terytorialnego, "Modern Management Review", 19.21(2), 2014, p. 49-160, J. Lampel, P.J. Pushkar, Models of project orientation in multiproject organizations [in:] P. Morris, J.K. Pinto (Ed.), The Wiley guide to managing projects, New York 2004, p. 223-236, E. Fuessinger Maturities of Project-Oriented Companies of About 15 Project-Oriented Nations, 2006 [online], A.K. Munns, B.F. Bjeirmi, The role of project management in achieving project success, International, "Journal of Project Management", 14(2), 1996, p. 81-87.

22 more: N. Brookes, R. Clark, Using Maturity Models to Improve Project Management Practice, 2009 [online:].

${ }^{23}$ more: H.R. Kerzner, Using the project management maturity model: strategic planning for project management, Ohio, 2011, H.R. Kerzner, Project Management: A Systems Approach to Planning, Scheduling and Controlling. 11 Edition, Ohio 2013, R. Gareis, Happy Projects!, Manz, Vienna 2005, Y.H. Kwak, C.W. Ibbs C.W., Assessing project management maturity, "Project Management Journal" 31(1), 2000, p. 32-43, T.J. Rodney, R. Müller, On the nature of the project as a temporary organization, "International Journal of Project Management", 21(1), 2003, p. 1-8, L. Lianyinga, H. Jinga, Z. Xinxinga, The Project Management Maturity Model and Application Based on PRINCE2, Procedia Engineering, 29, 2012, p. 3691-3697, E.S. Andersen, S.A. Jessen, Project maturity in organizations, "International Journal of Project Management", 21(6), 2003, p. 457-461, 
studies aim to prove the financial and organizational outcomes of adopting the projectoriented approach ${ }^{24}$.

The process and project-oriented approaches are not mutually exclusive. They supplement each other and the attempt to integrate them results from the challenges faced in today's business environment. This combined process-project approach would be called the task approach. Organizations must, therefore perfect the execution of tasks, both processes and projects. The approach typical for W.E. Deming's model of excellence (PDCA model) ${ }^{25}$ should be adopted. The model assumes that the ability to constantly monitor and perfect the solutions used within an organization forms the foundation for ongoing growth. This is what the Task-Oriented Organization Model, which is used in the presented study, is meant to achieve. The main aim of the model is to identify the level of task maturity and the development distance. By using this tool any organization may determine the activities necessary to increase the effectiveness.

\section{METHODOLOGY OF THE RESEARCH}

The investigation of task maturity is a multi-dimensional issue. Therefore, both the Task-Oriented Organization Model and its verification in the organization require a multicriteria analysis (MCA). There are many multi-criteria methods described in the literature, such as ANP, ELECTRE, PROMETHEE, TOPSIS, BIPOLAR, etc. ${ }^{26}$. They are meant to assist in the decision-making process, when faced with a complex problem consisting of many dimensions. In the research, the AHP method (Analytic Hierarchy Process) ${ }^{27}$ was selected as a base for creating the model and conducting the study because of a number of its notable characteristics, i.e. ${ }^{28}$ (1) relying on expert knowledge, (2) clearly structuring the issue, (3) grading the weights of the elements of the model by comparing them in pairs, (4) requiring expert opinions to be highly consistent with each other $(\mathrm{CR} \leq 0,10)$.

The Task-Oriented Organization Model, used in the research is a hierarchical AHP model built by particularizing the task-oriented organization. General dimensions have been identified - criteria $\left(\mathrm{C}_{\mathrm{i}}\right)$, sub-dimensions - sub-criteria of the first level $\left(\mathrm{SC}_{\mathrm{i}}\right)$, and parameters - sub-criteria of the second level $\left(\mathrm{SC}_{\mathrm{ij}}\right)$. The general structure of the model used is presented in Figure 1.

K.P. Grant, J.S. Pennypacker, Project management maturity: An assessment of project management capabilities among and between selected industries, Engineering Management, IEEE Transactions, 53(1), 2006, p. 59-68.

${ }^{24}$ T.J. Cooke-Davies, A. Arzymanow, The maturity of project management in different industries: An investigation into variations between project management models, "International Journal of Project Management" 21(6), 2003, p. 471-478.

25 P.J. Kolesar, What Deming told the Japanese in 1950, "Quality Management Journal”, 2(1), 1994, p. 9-24.

${ }^{26}$ T. Trzaskalik, Wielokryterialne wspomaganie decyzji. Przeglad metod i zastosowań, Zeszyty Naukowe Politechniki Śląskiej, OiZ, 74, 2014, p. 239-263., J.S. Dodgson, M. Spackman, A. Pearman, L.D. Phillips, Multi-criteria analysis: a manual, Department for Communities and Local Government, 2009.

27 T.L. Saaty, The Analytic Hierarchy Process, New York 1980.

${ }^{28}$ Advantages of this method ware fully described in: A. Prusak, P. Stefanów, op. cit. 


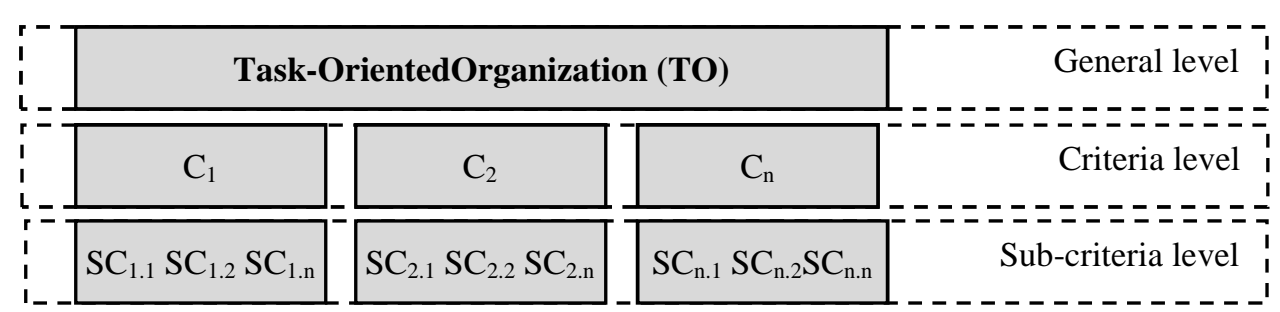

Fig. 1. Overview of the Task-Oriented Organization Model structure

Source: own work based on: A. Prusak, J. Strojny, P. Stefanów, Analityczny Proces Hierarchiczny (AHP) na skróty - kluczowe pojęcia $i$ literatura, ęHumanities and Social Sciencesę, 4/2014, p. 179-192.

The study was based on an existing Task-Oriented Organization Model by J. Strojny. Therefore, the scope of the research presented in this article does not include the conceptual phase, and focuses on the execution and analytical phases of the AHP procedure. In the first step, a group of experts was appointed. It included representatives of senior university management (administrators), managers (department managers) and executives (specialists in selected fields). The group of experts consisted of 12 individuals. The study was divided into two factual areas:

- analysis of preferences - examination of the significance of the individual elements of the model,

- assessment of the organization's task-orientedness level.

A preference analysis and subsequent assessment of the organization's attributes was carried out using the FGI (Focus Group Interview) method ${ }^{29}$. The interviews were divided into several sessions. The aim of the first session was to determine the significance of the elements of the model (all experts took part). During the second session, experts were divided into groups tasked with assessing specific areas of the organization.

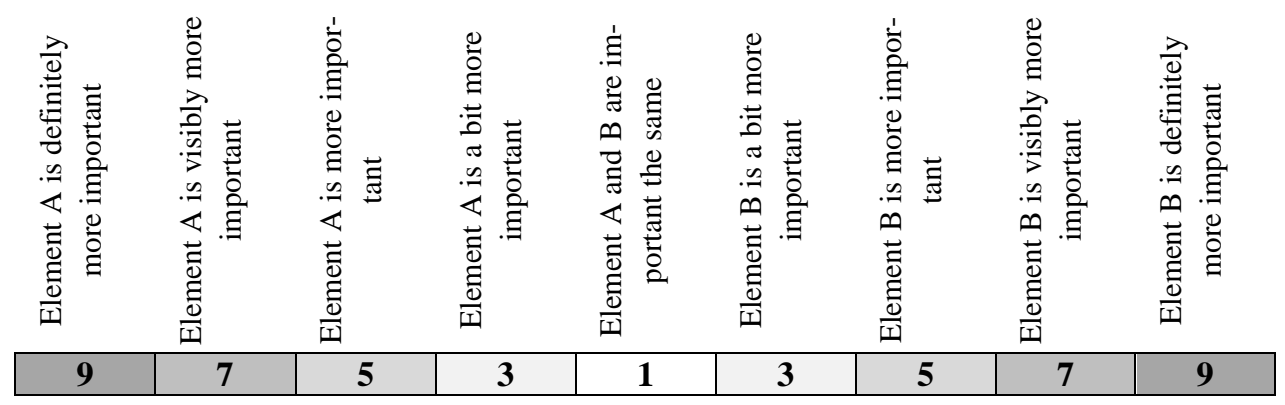

Fig. 2. The diagram of the Saaty' scale

Source: own work based on: A. Prusak, P. Stefanów, AHP - analityczny proces hierarchiczny, Warszawa 2014. ${ }^{29}$ This method was fully described in: J. Lisek-Michalska, P Daniłowicz (Ed.), Zogniskowany
wywiad grupowy. Studia nad metoda, Łódź 2009. 
During the first session, experts assessed the significance of the elements of the model, using pairwise comparisons with respect to the efficiency and effectiveness of the organization. The Saaty scale was used to make these judgements, which is typical for AHP analyses (Fig. 2). Experts had to choose which element in the pair compared was more important in achieving a high level of efficiency and effectiveness. If both elements were of equal importance, they marked a value of 1 . The more important the first element is over the second, the values go further to 9 .

Adopting the FGI method made it possible to aggregate judgements without statistical aggregation (e.g. using means). In the initial step, the experts assessed the significance by themselves and then discussed their choices within a group. Final decisions were made on the bases of this. Next, the inconsistency of their judgements was evaluated, using the index of CR (Consistency Ratio). It is recommended in the literature to achieve the value of the index as follow: $\mathrm{CR} \leq 0,10^{30}$. If assessments in a given cluster of the model proved inconsistent, the experts were asked to repeat the assessment and then once again explain the compared parameters. The equation for calculating the CR coefficient is as follows ${ }^{31}$ :

$$
C R=\frac{I C}{R}=\frac{\left(\lambda_{\max }-N_{e}\right):\left(N_{e}-1\right)}{R}=\frac{\left\lfloor\left(\sum_{i=1}^{n} \sum_{j=1}^{n} a_{i j} w_{i}\right)-N_{e}\right\rfloor:\left(N_{e}-1\right)}{R},
$$

where:

CRConsistancy Ratio,

ICInconsistency Index,

RRandom Index - values tabled by Saaty,

$\lambda_{\max }$ Maximal eigenvalue of the comparison matrix,

$\mathrm{N}_{\mathrm{e}}$ Number of compared elements,

$\mathrm{a}_{\mathrm{ij}}$ Value of comparison matrix element,

$\mathrm{w}_{\mathrm{i}}$ Weight coefficient of a given matrix element.

The weights of individual elements of the model are calculated using the comparison matrix. Detailed calculation procedures can be found in literature ${ }^{32}$. The calculations yield local and global weights. The former denote the significance of a given element in relation to a superior element within the criterion (placed higher in the hierarchy that it is a part of); whereas global weights denote the significance of a given element in relation to the main element (the research goal). The global weights of the sub-criteria are a product of their local weights and the weights of their superior criteria. During the next stage of the study, the local weights were used to achieve a weighted mark of the maturity level of the organization investigated.

During the second part of the study, the experts assessed the level of task maturity of the organization within specific areas. The assessment involved responses to diagnostic questions. Here the 5-point scale of maturity was used. The interpretation of each point of the scale is as follows:

\footnotetext{
30 A. Prusak, P. Stefanów, op. cit., p 253-255.

31 Ibidem.

32 more: Saaty T.L., Fundamentals of decision making, Pittsburgh 1994, A. Prusak, P. Stefanów, op. cit.
} 
- 1: there is no evidence that the organization is taking any steps in this area, nor is it aware of the necessity to take them,

- 2: there is evidence of the organization being aware of the necessity to take steps in this area, however there is no evidence that any steps are being taken,

- 3: there is evidence of the organization being aware of the necessity to take steps in this area, however there are considerable difficulties in effectively doing so,

- 4: there is evidence of the organization consciously taking steps in this area, and no major difficulties in doing so effectively have been observed,

- 5: there is evidence that the organization carries out all of the activities in the area consciously, effectively and with commitment, exhibiting considerable maturity and sector-wide innovativeness.

The arithmetic mean was used when aggregating marks, for the questions used to describe each parameter. Whereas, when aggregating values of the parameters and sub-criteria, the weighted value was used, using local weights achieved during the preference analysis (first stage of the research).

\section{DIMENSIONS OF THE TASK-ORIENTED ORGANIZATION MODEL}

The analytical model used in the study is holistic and includes numerous attributes of the organization. On a general level there are three basic dimensions: strategic, operational and socio-organizational.

Strategic dimension encompasses the characteristics of the organization that relate to it's achieving its long-term goals. It was divided into three first level sub-criteria:

- Management quality assurance comprehensive system,

- Stakeholder-focused decision-making system,

- Priority-based strategy.

The first of the sub-criteria relates to an important aspect of the organization's operations associated with the system of monitoring and improving the management process. This means undertaking activities that make it possible to constantly monitor the level of the company's effectiveness, as well as identify and remove all problems. Three processes underwent a detailed analysis: corporate governance, internal audit and controlling.

The ability to build relationships with stakeholders is crucial for the operations of today's organizations. The model goes beyond the CSR (Corporate Social Responsibility) approach in this respect. The search for a more effective way of gaining a strong competitive position through adopting the right policies towards specific groups of stakeholders has led to them being included in the strategic management process. The decision-making process, and especially the effectiveness of communications and keeping management informed, was taken into consideration when creating the model. The obstacles that may arise out of interpersonal relationships were also taken into account; as was the process of decentralizing the decision-making system.

The last of the sub-criteria relates to activities directly associated with strategy planning and implementation. First, the existence of a systematic approach to researching the competitive position of the organization had to be verified. It constitutes an important component of determining the strategic situation and may have a decisive influence on the goals themselves and the probability of attaining them. The analysis also ascertained whether the organization is able to prioritize strategic intents. This is indispensable when faced with limited resources, which is a common state in the economy. An organization may only grow 
if it is able to correctly choose the most important areas of operations and then focus on them. Of course, it is important to appropriately plan and control the strategy in given situations.

Strategic activities set the framework for an organization's operations. Their effectiveness, however, is also dependent on the operational layer. It is on that level that decisions are being made which, ultimately, should lead to achieving long-term goals and, thus, contribute to the growth of the organization.

Three first level sub-criteria were identified within this layer: a comprehensive management quality assurance system, a management accounting system, a specialized IT system.

The first operational management area that underwent analysis encompassed activities associated with categorizing tasks, managing their execution and the responsibility for their completion. Task-orientation involves precisely outlining the processes and projects that the organization must complete to achieve its goals. The task categorization system constitutes an axis of operational management by specifying which tasks are directly related to delivering specific products and services, and which tasks are indirect. It is also important to determine the principles of establishing projects in the organization's day-to-day operations. Of course, the tasks should be planned and their execution should be monitored. Assigning responsibilities between individuals involved in the organization's operations is another important factor for achieving effectiveness.

Of course, managing tasks requires management information to be prepared and available. This is what the next parameter, i.e. management accountancy, is meant to achieve. It allows for the preparation of information that meets the needs of the organization in the following areas: costs, effectiveness and liquidity. In the first area it is important to focus on the organization's ability to identify the outcomes of individual tasks and estimate the costs of achieving them (both direct and indirect). Measuring and analysing effectiveness is also indispensable for any organization. This includes return indicators, the use of which is widespread in the private sector, and the cost-effectiveness of the organization. On the other hand, liquidity analysis should provide a dynamic image of the organization's financial resources and cash flows. It is also necessary to implement analyses that will enable managing the risk of losing liquidity.

The importance of a systematic approach to the process of informing management was emphasized at the strategic level. The operational level supplements this with a number of guidelines concerning the scope of the data and how it is processed. Today's management methods require swift access to large amounts of management information, which is presented to the decision makers in an accessible way. Therefore, a task-oriented organization should also have the necessary IT systems in place. These should support the basic areas of the information process, including: managing tasks, resources and finances, document workflow, the decision-making process and communication.

The third layer covered by the study concerns the socio-organizational aspects of the organization. This element of the model supplements the other two by bringing to light the cultural and organizational conditions within which the strategic and operational management takes place. The layer was divided into three basic first level sub-criteria:

- Matrix organizational structure,

- Proactive organizational culture,

- Pro-effective motivational system. 
The Task-Oriented Organization Model sets the matrix structure, i.e. consisting both of a constant (hierarchical) and temporary (project) structure, as its goal. It is important that the two types of structure remain in balance to achieve the highest efficiency of management within a given organization. Both components of the structure were analysed. The hierarchical structure should clearly state who is responsible for each process within the organization; whereas the project structure should be strong enough, in relation to the hierarchical structure, to ensure that projects are carried out efficiently. The bigger the importance of projects, the more power the temporary structure should be given. Examining the organizational solutions ensuring the development of task-orientation was an additional element of the analysis. By this we mean a cell or a position, for example, responsible for fostering task-orientation.

The second element of the layer in question relates to organizational culture. The model outlines one of its characteristics, namely pro-activeness. It has been assumed that taskorientation is based on far-reaching decentralization of management, which greatly increases the need for individuals becoming engaged in reaching goals. It is necessary to create conditions in which they will be able to take risks and make independent decisions. Therefore, the analysis included the leadership model of the organization, the error acceptance culture that arises out of it, as well as the conditions for the development of intraorganizational entrepreneurship.

The desired employee behaviors should be encouraged by an appropriate motivational system. In general, the model adopts an approach based on the management by objectives philosophy in this regard. First, the principles of determining base remunerations underwent analysis. We have checked if they are consistent and whether base remunerations are determined in accordance with the type of work that is being done in a given position. The analysis also covered the manner in which variable remunerations are awarded and how they are influenced by the effective execution of tasks. A clear personal development system should be an additional motivating factor, albeit still coherent with the others. The analysis included both activities aimed at gaining qualifications and the promotion system in the organizational structure.

\section{ANALYSIS OF THE TASK MATURITY OF THE ORGANIZATION - RESEARCH RESULTS}

To enable the study, a private university located in central Poland was chosen. The university leads both educational processes, as well as those aimed at developing and commercializing science. At the same time, many of its activities are carried out using a projectbased approach. The organization is complex enough, and the scale of its activities is broad enough, to allow using complex concepts and methods of improving efficiency. The most important characteristic of the organization is its willingness to develop. Private universities in Poland are in fierce competition with each other, which encourages them to constantly seek new opportunities for improvement. Therefore, they are open to research projects that may potentially help them identify and evaluate their attributes. This kind of environment made it possible to carry out the research using the highest standards, which was very important for the authors of this article. This short description allows indicating that the organization meet the established criteria of selection, which are: accessibility, compatibility and usability. The chosen organization was accessible, as the authorities of the university 
are open to implementing new methods of perfecting the management processes. The organization was also compatible with the assumptions of the Task-Oriented Organization Model. It uses both, processes and projects (at least a few major ones each year), and is large enough to allow for the use of more refined management concepts and methods. Finally, the results achieved can be used to improve efficiency and effectiveness.

The result of the first part of the study is to assess the significance of the individual elements of the Task-Oriented Organization Model. Both scales, local and global are shown in Table 1. They are presented at the level of criteria and sub-criteria.

Tab. 1. The Task-Oriented Organization Model structure and weights

\begin{tabular}{|c|c|c|c|}
\hline \multicolumn{2}{|c|}{ Model elements } & \multirow{2}{*}{$\begin{array}{c}\text { Local weights } \\
100.00 \%\end{array}$} & \multirow[t]{2}{*}{ Global weights } \\
\hline & Task-Oriented Organization & & \\
\hline 1 & Strategic dimension & $69.56 \% *$ & \\
\hline 1.1 & $\begin{array}{l}\text { Comprehensive management quality assurance sys- } \\
\text { tem }\end{array}$ & $7.19 \% * *$ & $5.00 \%$ \\
\hline 1.2 & Stakeholder-focused decision-making system & $27.90 \% * *$ & $19.40 \%$ \\
\hline 1.3 & Priority-based strategy & $64.91 \% * *$ & $45.15 \%$ \\
\hline 2 & Operational dimension & $22.90 \% *$ & \\
\hline 2.1 & Comprehensive task management system & $20.81 \% * * *$ & $4.77 \%$ \\
\hline 2.2 & Management accountancy system & $66.08 \% * * *$ & $15.13 \%$ \\
\hline 2.3 & Specialized IT system & $13.11 \% * * *$ & $3.00 \%$ \\
\hline 3 & Organizational and social dimension & $7.54 \% *$ & \\
\hline 3.1 & Matrix organizational structure & $62.67 \% * * * *$ & $4.73 \%$ \\
\hline 3.2 & Proactive organizational culture & $28.97 \% * * * *$ & $2.11 \%$ \\
\hline 3.3 & Pro-effective motivation system. & $9.36 \% * * * *$ & $0.71 \%$ \\
\hline
\end{tabular}

Source: authors' own research.

The experts were of the opinion that the most important criterion of the organization's effectiveness is the strategic area (a weight of almost 70\%). It was determined that accurately identifying trends and focusing on taking advantage of them will be key for the university's growth in a highly-competitive environment. Therefore, priority orientation was selected as the most important component of the strategic layer (a weight of almost 65\%). Since the university has limited resources, it must skilfully identify those avenues of development that will bring it the most benefits in the future. Maintaining and developing relationships with stakeholders also continues to be important (a weigh of almost 28\%). The operational layer was in part regarded as resulting from the strategic layer. That would explain its irrelevance. Among the operational activities, the importance of management accountancy was emphasized in particular, being considered a valuable source of management information. The socio-economic layer was considered to be the least relevant (a weight of only 7.5\%). The matrix organizational structure, which allows for effectively combining processes and projects, was considered the most relevant in this layer. 
The attributes of task orientation that contribute the most to the organization's effective operations were identified using global weights. The three most important characteristics are: (1) a priority-based strategy $(45.15 \%)$, (2) a stakeholder-focused decision-making system (19.40\%) and (3) a management accountancy system (15.13\%). The remaining attributes were considered to be significantly less relevant.

The final step of the study involved assessing the level of the organization's task-orientation. The grades obtained through the diagnostic questions were aggregated in accordance with the principles outlined in the section on methodology. Due to space constraints, this article will present the results of the assessment of task orientation on a general level, the level of the criteria and sub-criteria of the first level.

The overall grade of the organization was equal to 4.48 points. This means that the organization is being managed in an almost exemplary manner in many areas. However, we would like to remind you that the above result is a weighted grade that takes into account the preferences of the organization's experts. A curious phenomenon was observed in the organization, which should probably be expected due to its focus on priorities. It turned out that the organization reached a high level of maturity in the areas that it considers the most relevant. On the other hand, low maturity was recorded in areas that are considered irrelevant.

As regards criteria, the operational layer was rated the highest and the socio-organizational layer was rated the lowest. The results are presented in Figure 3.

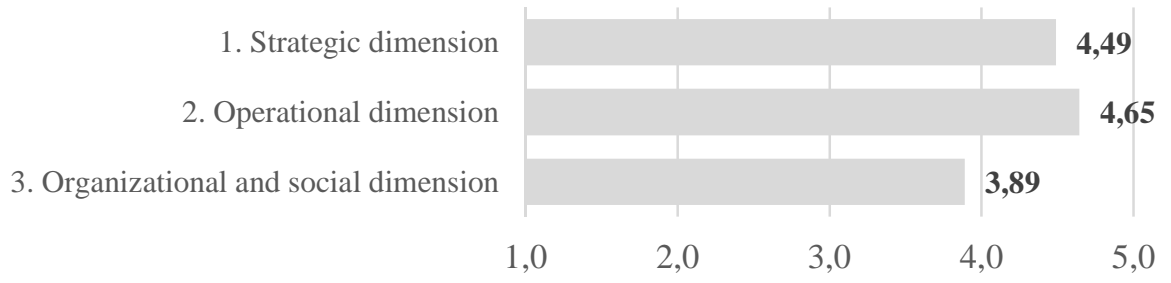

Figure 3. Assessment of the task maturity level of the organization using the criteria set of the TaskOriented Organization Model

Source: authors' own research.

Examining the sub-criteria of the first level resulted in a more detailed image of the organization. Figure 2 presents the grades that were obtained. Management accountancy received the highest grades in the organization (4.87 points). The university has implemented a cost management system that allows analysis of their structure and deviations. Budgets of both processes and projects are determined predominantly by estimating how labor intensive the tasks are, but other resources necessary for completing them are also taken into account. An organization effectiveness management system has also been implemented. Individual tasks are monitored examine effectiveness. The grade in this area was lower than it could be because a system of analysing the effectiveness of individual cells and employees is currently being implemented, but is not yet operational. The organization has also implemented a liquidity management system. It is monitored dynamically by analysing changes in schedules. Risk management has also been implemented, both through 
securing project resources and periods of decreased revenue. Another distinguishing element in this regard is the ongoing diversification of revenues, which allows the organization to have more freedom in shaping its liquidity policy. The implemented solutions surely go beyond the basics typical for the higher education sector in Poland ${ }^{33}$.

The ability of an organization to implement a priority-based strategy also received high grades (4.80 points). The organization has also implemented solutions in this area that distinguish it among its competitors in the sector. First, a system of monitoring the university's competitiveness and competitive position has been implemented. The research in this area is carried out by a cell set up especially for this purpose. The available courses are being updated on an ongoing basis to satisfy current market demand or even anticipate future trends. Benchmarking is also widely used. The university has defined its growth priorities and is consciously pursuing them. This is attested not only by strategic documents, but also the approach to operational activities. A number of very interesting and unique solutions have been implemented in the area of strategy planning and controlling. The most important among them is the Strategy Controlling Committee headed by a Vice Rector. Among the members of the committee are other senior university officials. Special analytical tools and management methods are used to monitor the strategy, including the execution of tasks and reaching goals. The entire process is aided by the use of suitable computer software.

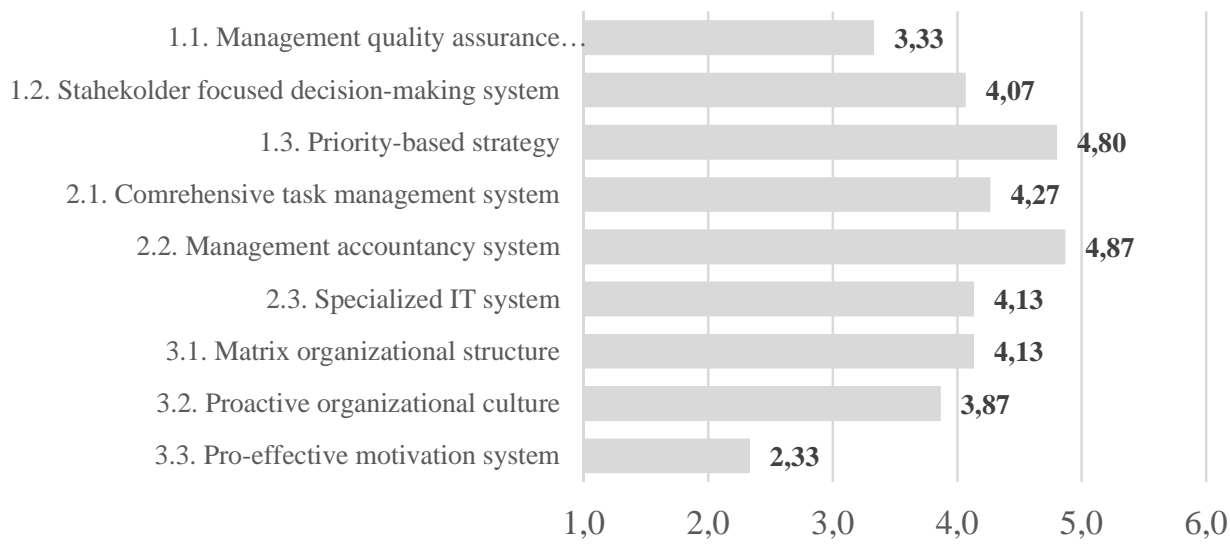

Figure 4. Assessment of the task maturity level of the organization using the sub-criteria set of the Task-Oriented Organization Model

Source: authors' own research.

Two areas of the organization's operations received low grades - the comprehensive management quality assurance system (3.33 points) and the pro-effective motivational system (2.33).The organization has implemented some components of corporate governance. The Chancellor is in charge of overseeing it. The system analyses the risk of the university's activities across various areas. Some challenges were also faced when translating strategic goals into operational ones. Therefore, operational activities are not always consistent and do not result in synergy. There is also a problem in developing the task execution

${ }^{33}$ more: M. Baran, J. Strojny, op. cit., p. 247-262. 
monitoring system. It stems not out of the lack of available information, but rather from its inefficient flow. The organization is only now implementing an internal auditing system. Therefore, an improvement process based on internal audits is not implemented. This applies especially to the operational layer. Similar functions in the strategic layer are already being handled by a special organizational unit. A similar situation may be observed in the area of controlling. A systematic approach is currently being implemented. Financial controlling is being broadened to include other areas with the aim of delivering full operational controlling. It should be noted that controlling is doing fairly well in the strategic layer.

The pro-effective motivational system has received the lowest grades of all areas. The organization is currently in the early stages of preparations for implementing a systematic approach to pro-effective motivation. The issue now is the low transparency of the remuneration system. This may lead to demotivating individuals who do not understand or do not accept the current remuneration scheme. As was emphasized earlier, the organization has trouble with operationalizing goals. This makes it impossible to implement the principles of the Management by Objectives method. Individual cells and people are not being fully monitored and evaluated with regard to their meeting the organization's goals. A lack of systematic approach to the personal development policy of employees is another big complication. The organization is currently focused on the cadre function (payroll systems). There is, however, no HR (Human Resource) function. For this reason, there are no competence development systems and career paths in place.

The study made it possible to determine the strengths and weaknesses of the organization rated against the exemplary model of task-orientation organization. The below recommendations, allowing for the initiation of development project or projects, were devised based on the analysis presented above:

- implementing the Balanced Scorecard method as a tool for operationalizing strategic goals,

- implementing an operational controlling system based on the existing cell tasked with performing strategic controlling (Centre for Analyses),

- transforming the Centre for Analyses into to the Controlling and Internal Audit Centre, and making the cell responsible for leading all processes associated with gathering and processing management information,

- implementing corporate governance principles in accordance with the guidelines issued by the Minister of Finance and assigning the Chancellor as the supervisor of management quality,

- implementing a new remuneration system with base salaries calculated using appraisals of work performance, and individual and group bonus systems determined by the extent to which the organization's goals are met,

- implementing a personnel strategy linked to the university's development strategy, encompassing both a competence development policy (including employee screening) and an employee satisfaction monitoring system.

The above recommendations were presented to the officials of the organization. They were deemed relevant and valid. This allowed us to achieve the utilitarian goal of the study, i.e. the analysis proved useful for practical management purposes. 


\section{CONCLUSIONS}

To summarize results of the research formulated conclusions in three dimensions: cognitive, utilitarian and methodological.

The cognitive goal was achieved by providing answers to the two detailed research questions. The weights of the individual elements of the model were identified. It was determined that the three most important characteristics of the organization that contribute to its task-orientation are: a priority-based strategy, a stakeholder-focused decision-making system and a management accountancy system. The cognitive aspect also made it possible to determine the characteristics that received low grades (the management quality assurance system and the pro-effective motivational system). They offer an interesting opportunity for the organization to grow. This also allowed us to reach the utilitarian goal by identifying the most important areas of reorganization.

The study was also tasked with verifying the model itself and the procedure for scrutinizing it. Discussions between experts were observed during the research. This allowed us to identify the basic guidelines for further improving the model. The main conclusions concern its structure and the description of characteristics using diagnostic questions. As regards the structure, the entire model should be rebuilt and the main criteria should be revised. One possibility is to combine the model with the Balanced Scorecard strategy. With respect to the diagnostic questions, it is worth considering putting more emphasis on the organization's willingness to improve (e.g. in accordance with Deming's PDCA model). It may also prove useful to define specific checklists containing the desired solutions within detailed areas. That could aid in assessing the current state of the organization and, simeultaneously, allow comparing it against other organizations.

The methodological goal also required verification of the research procedure. The adopted approach seems correct. Neither selecting suitable experts with knowledge of the various areas of the university's operations, nor employing the FGI method have led to any issues emerging during the course of the study. The mechanism of reaching a common grade within groups of experts was also rated positively. It seems to be more fitting for the model than, for example, statistical aggregation methods. The quality of the information obtained concerning the characteristics of the organization in question was also rated highly by the management of the organization. It seems that, despite some shortcuts, the study correctly identified the university's strengths and areas in need of improvement.

\section{REFERENCES}

[1] Andersen E.S., Jessen S.A., Project maturity in organizations, "International Journal of Project Management", 21(6), 2003, p. 457-461.

[2] Baran M., Strojny J., Kompleksowe podejście do zarządzania projektami na przykładzie uczelni wyższej, „,Przedsiębiorczość i Zarządzanie”, Wydawnictwo SAN, XIV.12.I, 2013, p. 247-262.

[3] Brookes N., Clark R. Using Maturity Models to Improve Project Management Practice, 2009 [online:] Available at: http://pomsmeetings.org/ConfProceedings/011/FullPapers/ 011-0288.pdf [Assessed 18 September 2017].

[4] Cooke-Davies T.J., Arzymanow A., The maturity of project management in different industries: An investigation into variations between project management models, "International Journal of Project Management” 21(6), 2003, p. 471-478. 
[5] Dodgson J.S., Spackman M., Pearman A., \& Phillips L.D., Multi-criteria analysis: a manual, Department for Communities and Local Government, 2009.

[6] Fuessinger E., Maturities of Project-Oriented Companies of About 15 Project-Oriented Nations, 2006 [online] Avaliable at: <http://www.icoste.org/Slovenia2006Papers/icecFina 100100.pdf> [Assessed 18 September 2017]

[7] Gareis R., Happy Projects!, Manz, Vienna 2005.

[8] Gasparski W., Prakseologia-wariacje na temat..., „Prakseologia” 150, 2010, p. 25-34.

[9] Grant K.P, Pennypacker J.S., Project management maturity: An assessment of project management capabilities among and between selected industries, Engineering Management, IEEE Transactions, 53(1), 2006, p. 59-68.

[10] Hammer M., Champy J., Reengineering w przedsiębiorstwie, Neumann Management Institute, Warszawa 1996.

[11] International Project Management Association (IPMA), IPMA Organizational Competence Baseline - The standard for moving organizations forward, IPMA, Zurich, 2013.

[12] Jackson T.L., Implementing a lean management system, CRC Press, Portland 1996.

[13] Jackson M., Systems approaches to management, Springer Science \& Business Media, New York 2007.

[14] Kanji G.K., Total quality management: the second industrial revolution, "Total Quality Management", 1(1), 1990, p. 3-12.

[15] Kast F.E., Rosenzweig J.E., General systems theory: Applications for organization and management, "Academy of management journal", 15(4), 1972, p. 447-465.

[16] Kerzner H., Project Management: A Systems Approach to Planning, Scheduling and Controlling. 11 Edition,John Wiley \& Sons, Ohio 2013.

[17] Kerzner H.R., Using the project management maturity model: strategic planning for project management, John Wiley \& Sons, Ohio 2011.

[18] Kolesar P.J., What Deming told the Japanese in 1950, “Quality Management Journal”, 2(1), 1994, p. 9-24.

[19] Kotarbiński T., Traktat o dobrej robocie, Ossolineum, Wrocław-Warszawa-KrakówGdańsk 1973.

[20] Kowal W., Skuteczność i efektywność-zróżnicowane aspekty interpretacji, „Organizacja i Kierowanie", 157(4), 2013, p. 11-22.

[21] Kwak Y.H, Ibbs C.W., Assessing project management maturity, "Project Management Journal" 31(1), 2000, p. 32-43.

[22] Lampel J., Pushkar P.J., Models of project orientation in multiproject organizations [in:] P. Morris, Peter, J.K. Pinto (Ed.), The Wiley guide to managing projects, Hoboken, John Wiley \& Sons, New York 2004, p. 223-236.

[23] Lianyinga L., Jinga H., Xinxinga Z., The Project Management Maturity Model and Application Based on PRINCE2, Procedia Engineering, 29, 2012, p. 3691-3697.

[24] Lisek-Michalska J., Daniłowicz P. (Ed.), Zogniskowany wywiad grupowy. Studia nad metoda, Wyd. Uniwersytetu Łódzkiego, Łódź 2009.

[25] Mazur M., Pojęcie systemu i rygory jego stosowania, „Postępy Cybernetyki” 10(2), 1987, p. 25-33.

[26] Mazurkiewicz A., Sprawność działania - interpretacja teoretyczna pojęcia, Nierówności Społeczne a Wzrost Gospodarczy, (20), 2011, p. 47-57.

[27] Midgley G. (Ed.)., Systems thinking, Sage, London 2003. 
[28] Munns A.K., Bjeirmi B.F., The role of project management in achieving project success, International, "Journal of Project Management", 14(2), 1996, p. 81-87.

[29] Mynarski S., Elementy teorii systemów i cybernetyki, Państwowe Wydawnictwo Naukowe, Warszawa 1981.

[30] Office of Government Commerce (OGC). Managing Successful Projects with PRINCE2 ${ }^{\mathrm{TM}}$, TSO, London 2009.

[31] Powell T.C., Total quality management as competitive advantage: a review and empirical study, "Strategic Management Journal", 16(1), 1995, p. 15-37.

[32] PMI - Project Management Institute, Organizational Project Management Maturity Model (OPM3®) - Third Edition, PMI, Pennsylvania 2013.

[33] PMI - Project Management Institute, A Guide to the Project Management Body of Knowledge (PMBOK® Guide), 5th Edition. PMI, Pensylvania 2013.

[34] Prusak A., Strojny J., Stefanów P., Analityczny Proces Hierarchiczny (AHP) na skróty kluczowe pojęcia i literatura, „Humanities and Social Sciences”, 4/2014, p. 179-192.

[35] Prusak A., Stefanów P., AHP - analityczny proces hierarchiczny, CH Beck, Warszawa 2014.

[36] Pszczołowski T., Zasady sprawnego działania. Wstęp do prakseologii, Wiedza Powszechna, Warszawa 1982.

[37] Quin A.J., Cybernetics in management, Systems Science, Springer US, 1993, p. 199-204.

[38] Rodney T.J., Müller R., On the nature of the project as a temporary organization, "International Journal of Project Management", 21(1), 2003, p. 1-8.

[39] Saaty T.L., Fundamentals of decision making, RWS Publications, Pittsburgh 1994.

[40] Saaty T.L., The Analytic Hierarchy Process, McGraw-Hill, New York 1980.

[41] Singh J., Singh H., Kaizen philosophy: a review of literature, "IUP Journal of Operations Management", 8(2), 2009, p. 51-72.

[42] Strojny J., Task-Oriented Organization Model - documentation, unpublished materials, Rzeszów 2015.

[43] Strojny J., Organizacyjne i proceduralne uwarunkowania zarzadzania projektami $w$ jednostce samorzqdu terytorialnego, „Modern Management Review”, 19.21(2), 2014, p. $49-160$.

[44] Trzaskalik T., Wielokryterialne wspomaganie decyzji. Przeglad metod i zastosowań, Zeszyty Naukowe Politechniki Śląskiej, OiZ, 74, 2014, p. 239-263.

\section{ANALIZA POZIOMU ORIENTACJI ZADANIOWEJ. PRZYKLAD POLSKIEGO UNIWERSYTETU NIEPUBLICZNEGO}

Kwestia efektywności zarządzania jest niezwykle istotnym przedmiotem rozważań teoretycznych i problemem praktycznym. Dotyczy to zarówno przedsiębiorstw, instytucji publicznych, jak i organizacji pozarządowych. Tego zagadnienia nie można pominąć także w kontekście funkcjonowania współczesnych uniwersytetów. W literaturze istnieje wiele rozwiązań systemowych, które mają na celu zapewnienie wysokiej sprawności. Można wskazać wiele koncepcji zarządzania procesami, a także metodologii zarządzania projektami. W rzeczywistości wielu współczesnych organizacji oba rodzaje aktywności (projektowa i procesowa) mają niezwykle istotne znaczenie. Uzasadnia to poszukiwanie koncepcji łączących oba podejścia. 
Celem niniejszego artykułu jest prezentacja pilotażowego badania poziomu dojrzałości zadaniowej na jednej z polskich uczelni niepublicznych. Założono, że przyjęcie przedstawionego w artykule podejścia służy zapewnieniu wysokiej sprawności operacyjnej i strategicznej. Do analizy sytuacji wykorzystano metodę AHP (Analytic Hierarchy Process). Model orientacji zadaniowej zaproponowany przez J. Strojnego został przeanalizowany przez zespół kilkunastu ekspertów powołanych w ramach badanej uczelni. Miał on za zadanie dokonać zarówno weryfikacji istotności elementów proponowanego modelu, jak i oceny poziomu dojrzałości zadaniowej badanej organizacji. Każdemu wymiarowi głównemu modelu odpowiadała jedna sesja wywiadów. Oceny ekspertów zostały uzgodnione w ramach wywiadu grupowego, nie wymagały zatem agregacji z wykorzystaniem metod matematycznych. Oceny dojrzałości na poziomie kryteriów oraz ogólnym agregowano za pomocą średniej ważonej. Zastosowano tutaj wagi lokalne (oceny istotności elementów modelu). Wyniki analizowano pod kątem aspektów poznawczych, metodologicznych i utylitarnych.

Słowa kluczowe: Zarządzanie projektami, zarządzanie procesami, zarządzanie systemowe, uniwersytet, metoda AHP.

DOI: $10.7862 /$ rz.2017.hss.79

Przestano do redakcji: czerwiec $2017 \mathrm{r}$.

Przyjęto do druku: grudzień 2017 r. 